\title{
レーザー砕石装置の特性とその使用経験
}

\begin{tabular}{|c|c|c|c|c|}
\hline \multicolumn{5}{|c|}{ 東京医科大学泌尿器科学教室 } \\
\hline 哲夫 & 三木 誠 & 間宮 & 良美 & 平田 \\
\hline 弘文 & 栃本 & 伊藤 & 貴章 & 秋鹿 \\
\hline
\end{tabular}

\section{PECULIARITY OF PULSED DYE LASER LITHOTRIPTOR AND ITS CLINICAL APPLICATION}

\author{
Tetsuo Matsumoto, Makoto Miki, Yoshimi Mamiya, Touru Hirata, Hirobumi Shimizu, \\ Masato Tochimoto, Takaaki Ito and Tadao Aika \\ Department of Urology, Tokyo Medical College
}

Ultrasound lithotriptors (USL) and electrohydraulic lithotriptors (EHL) are representative lithotriptors for endoscopic eliminaiton of upper urinary tract stones. However, they have some disadvantages. For example, USL can not be used with flexible scopes and EHL can cause unexpected tissue injury. To overcome these problems, the pulsed dye laser lithotriptor (MDL-1, Candera Co.) was developed. The characteristics of this laser lithotriptor and its direct effects on tissue was investigated.

This pulsed dye laser lithotriptor generates a $504 \mathrm{~nm}$ wavelength green light beam by using a combination of a xenon flash lamp and the greenish dye composed of coumarin solution. The maximum output energy is $60 \mathrm{~mJ} /$ pulse and the pulse duration is 1.5 microsecond. The pulse rate can be varied from 1 to $20 \mathrm{~Hz}$.

First, the intensity of the shock wave was measured by using a combination of a piezoelectric element and an oscilloscope, and then, the results were compaired with those obtained by a similar experiment with an EHL. The average intensity of the shock wave was $54.4 \mathrm{~mW}$ under the conditions of $40 \mathrm{~mJ} /$ pulse of output energy and $10 \mathrm{~Hz}$ of pulse duration. On the other hand, the EHL generated an average of $54.7 \mathrm{~W}$ under the conditions of $400 \mathrm{~mJ} /$ pulse output energy. Then, fragmentation of various kinds of urinary stones in saline solution was performed. The results showed that this lithotriptor could fragment almost all kinds of stones except cystine stones. Then, hen's eggs were used to observe the effect if laser bean influenced on the organism immediately behind the photoradiated object. Only the egg shell was demolished but the egg membrane below the eggshell did not undergo any change. After these experiments, skin, liver, kidney and urinary bladder of nude mice and human prostatic urethral mucosa in case of TUR-P were irradiated by this laser. The results showed that laser energy caused slight penetration and localized hemorrhage from the surface of epithelium to subcutaneous tissue. It was confirmed that these effects were generated when the tip of the quartz fiber was in direct contact with the object.

After these investiagtions, fragmentation using this laser lithotriptor was attempted in thirty cases of upper urinary tract calculi. These 30 cases involved five cases of renal calculi and 25 cases of ureteral calculi. Percutaneous nephrolithotomy (PNL) was performed in 22 cases and transurethral ureterolithotomy (TUL) was performed in 8 cases. Twenty-four stones $(80 \%)$ were fragmented successfully. However, in six cases, stones which were smooth surfaced, hard and large could not be fragmented. The side effects of laser lithotriptor, slight hemorrhage from the ureteral mucosa, was observed in 2 cases.

We think that this laser lithotriptor is one of the most effective instruments for fragmenting urinary stones by TUL, especially TUL with a flexible scope, because this lithotriptor uses a very thin flexible quartz fiber and it dose not require protection of tissue from injurying while fragmenting calculi.

Key words: pulsed dye laser, urinary tract calculi, lithotriptor 
要旨：内視鏡による上部尿路結石摘出術 $(\mathrm{PNL}, \mathrm{TUL})$ に使用する砕石装置としては, 超音波砕石装置 (USL) や電気水圧砕石装置 (EHL) が一般的である。最近，それらの研石装置にない特徴を有するパル ス波色素レーザー砕石装置（MDL-1，Candela 社製）が開発された。本装置の特性，生体への影響につ いて検討した上で，それを上部尿路結石症 30 例に用いたのでその成績を報告する.

導光ファイバー先端に発生する衝撃力を压電素子とオシロスコープを組合せて測定した結果. $20 \mathrm{~mJ} ・ 1$ $\mathrm{Hz}$ で平均 $23.4 \mathrm{~mW}, 40 \mathrm{~mJ} \cdot 10 \mathrm{~Hz}$ で $54.4 \mathrm{~mW}$ であり, EHLの衝撃力に比し極めて弱いものであった. ま た生体に与兄る影響も EHLに比べて軽微で，直接導光ファイバー先端に接触した状態でレーザー光が 照射されたとさのみ，上皮ないし上皮下組織までの小穿孔と軽度の出血が認められた。シスチン結石以 外の結石は破砕可能であったが,この砕石効果も導光ファイバー先端が直接接触したときだけであった。

臨床例では腎結石 5 例，尿管結石 25 例に対し，PNL 22 例に，TULを 8 例に実施した。 24 例，80\% で良好な砕石効果が認められたが，表面平滑な硬い結石では砕石が困難であった。副作用として 2 例で 尿管粘膜の軽度出血を認めた。本装置は，細く柔軟な導光ファイバー $(\phi 0.25 \mathrm{~mm})$ を用い, 生体に与克 る影響が少ないという点で優れた砕石装置である。今後，TUL 用の砕石装置として普及するであろう。 キーワード：パルス波色素レーザー, 尿路結石症, 砕石装置

\section{緒 言}

近年，尿路結石症の治療法はめざましい進歩発展を とげ，体外衝撃波砕石装置 (以下 ESWL と略) による 非観血的治療法々経皮的腎尿管結石摘出術 (以下 PNL と略)，経尿道的腎尿管結石摘出術 (以下 TUL と略) に代表される内視鏡的治療法が主流となっている。 PNL や TULに際しては, 結石を砕石し摘出するため の各種装置, 器具が必要であり, 超音波砕石装置（以 下 USL と略)や, 電気水圧砕石装置(以下 EHL と略), バスケットカテーテルなどが一般的に使用されてい る。普通の USL は, 砕石能力の他, 吸引能力も有し有 用な砕石具であるが1)先端部分に長い金属パイプを用 いるため硬性鏡でのみ使用可能であり，軟性鏡には使

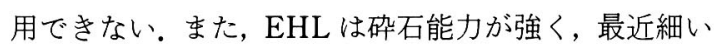
プローブが開発され細径の軟性鏡での使用も可能々 なったが，誤って腎盂・尿管粘膜に接触させて作動さ せると生体組織に大きな損傷を与える危険性があ る2).そこに登場したのが, 屈曲自在の細いファイバー を持ら生体組織に大きな損傷を与兄ず，充分な哗石能 力を有するというパルス波色素レーザー砕石装置 (MDL-1，Candela 社製）である.

このたび，この第 3 の砕石装置ともいうべきパルス 波色素レーザー砕石装置について, 砕石能力, 生体に 及ぼす影響などの基礎的問題を検討した上で，それを 臨床例に応用したのでその成績を報告する.

\section{パルス波色素レーザー砕石装置の概略}

本装置の外形を図 1 に示す。利用するレーザーはキ セノンフラッシュランプを光源とし, 緑色の色素ュー マリングリーンを用いて $504 \mathrm{~nm}$ の緑色光を発振させ
圀 1 上：パルス波色素レーザー砕石装置，下：細く柔軟な 導光ファイバー
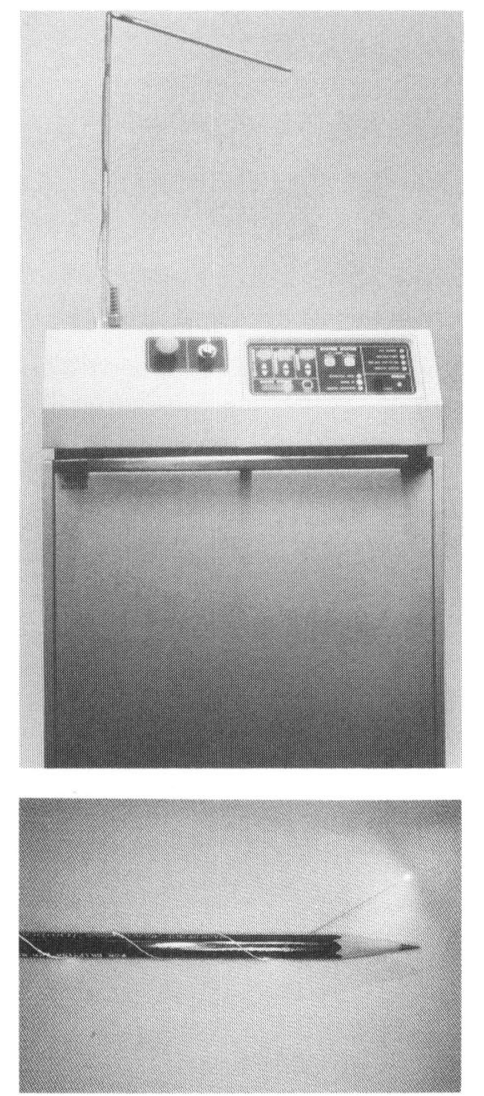

るパルス波色素レーザーである。パルス幅は1.5micro sec., パルス数は1 20Hz の間で可变である. 先端出力 
は20 60mJ で, $10 \mathrm{~mJ}$ の調節が可能となっている. 電 源は 3 相 $200 \mathrm{~V}$ で, 冷却水として $1.4 \mathrm{~kg} / \mathrm{cm}^{2}$ の水圧を有 する流水を必要とする。この装置から発振されたパル ス波色素レーザーは, コア径 $0.2 \mathrm{~mm}$, 外形 $0.25 \mathrm{~mm}$ の 細く柔軟なクオーツ導光ファイバーにより目的とする 部位に送られる。

\section{砕石能力に関する検討}

\section{1. 方法}

クオーツ導光ファイバー先端に発生する衝撃力を測 定するため, 図 2 のごとく圧電素子, オシロスコープ を組み合せた装置を作製した。圧電素子を生理食塩水 に入れ，その表面から $10 \mathrm{~mm}$ 離れた所にファイバーの 先端を固定し、レーザーを発振させて衝撃力を電気的 に変換し，オシロスコープ上で測定した。 また，対照 として EHL（オリンパス Lithostor EL-21）のプロー ブ先端出力を同様の方法で測定した。

なお，導光ファイバー先端を圧電素子の表面に接触 させた状態で衝撃力を測定する方が正しい測定法であ ると考学たが，この方法ではオシロスコープ上では衝 撃力はほとんど測定できなかったため,ファイバー先 端を $10 \mathrm{~mm}$ 離して測定を行った。

次に実際の䂶石能力を観察するため，これまで我々 が観血的手術により摘出した尿路結石や胆石を対象に 砕石実験を行った。尿路結石は蓚酸カルシウム, 燐酸 カルシウム, 尿酸, 燐酸マグネシウムアンモニウム, シスチンの 5 種類, 胆石はビリルビン結石のみについ
圀 2

圧電素子による衝撃力の測定

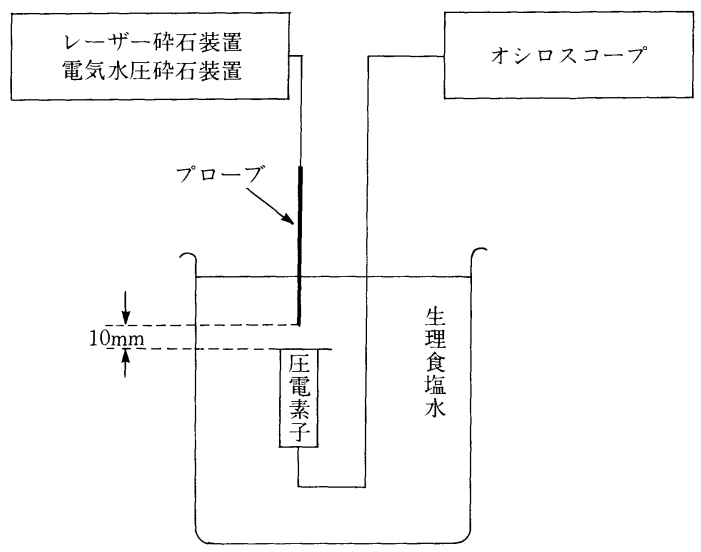

て実施した。これらの結石を生理食塩水を満たした ビーカーに入れ，導光ファイバー先端を結石の表面に 接触させてレーザーを発振した。照射条件は先端出力 $30 \mathrm{~mJ}$ ，パルス数は $10 \mathrm{~Hz}$ とした。

\section{2. 結果}

導光ファイバー先端に発生する衝撃力の測定結果は 表 1 に示すごとくである．先端出力 $20 \mathrm{~mJ} ・ 1 \mathrm{~Hz}$ では, 10 回測定の平均値が $23.4 \mathrm{~mW}, 40 \mathrm{~mJ}, 1 \mathrm{~Hz}$ のそれは $37.7 \mathrm{~mW}$ であった。 また $20 \mathrm{~mJ} \cdot 10 \mathrm{H}$ では $35.5 \mathrm{~mW}, 40$ $\mathrm{mJ} \cdot 10 \mathrm{~Hz}$ では $54.4 \mathrm{~mW}$ であり，エネルギーとパルス を上げれば当然のことながら衝撃力も上昇すると考克

表 1 電生素子, オシロスコープを用いた衝撃力の測定

$1 \mathrm{~Hz}$

(単位 $: \mathrm{mW}$ )

\begin{tabular}{|c|c|c|c|c|c|c|c|c|c|c|c|c|}
\hline \multirow{7}{*}{$\begin{array}{l}\text { レ } \\
\text { I } \\
\text { ザ } \\
\text { I } \\
\text { 研 } \\
\text { 装 } \\
\text { 置 }\end{array}$} & $\begin{array}{l}\quad \text { サンプル } \\
\text { エネ } \\
\text { ルギー }(\mathrm{mJ})\end{array}$ & 1 & 2 & 3 & 4 & 5 & 6 & 7 & 8 & 9 & 10 & $\mathrm{x}$ \\
\hline & 20 & 23.5 & 22.5 & 21.5 & 23.0 & 23.5 & 23.0 & 24.5 & 23.0 & 26.0 & 23.0 & 23.4 \\
\hline & 40 & 57.0 & 33.5 & 35.0 & 34.0 & 37.0 & 36.5 & 39.0 & 33.5 & 37.5 & 37.5 & 37.7 \\
\hline & \multicolumn{10}{|c|}{$10 \mathrm{~Hz}$} & \multicolumn{2}{|c|}{ (単位 $: \mathrm{mW}$ ) } \\
\hline & $\begin{array}{l}\quad \text { サンプル } \\
\text { エネ } \\
\text { ルギー }(\mathrm{mJ})\end{array}$ & 1 & 2 & 3 & 4 & 5 & 6 & 7 & 8 & 9 & 10 & $\mathrm{x}$ \\
\hline & 20 & 36.5 & 35.5 & 34.5 & 36.5 & 35.0 & 34.5 & 35.5 & 36.0 & 37.0 & 33.5 & 35.5 \\
\hline & 40 & 56.5 & 56.5 & 55.0 & 55.5 & 53.5 & 54.5 & 52.5 & 52.5 & 53.0 & 54.0 & 54.4 \\
\hline & & & & \multicolumn{7}{|c|}{$10 \mathrm{~Hz}$} & \multicolumn{2}{|c|}{ (単位：W) } \\
\hline \multirow{3}{*}{$\begin{array}{l}\mathrm{E} \\
\mathrm{H} \\
\mathrm{L}\end{array}$} & $\begin{array}{l}\text { サンプル } \\
\text { エネ } \\
\text { ルギー }(\mathrm{mJ})\end{array}$ & 1 & 2 & 3 & 4 & 5 & 6 & 7 & 8 & 9 & 10 & $\mathrm{x}$ \\
\hline & 200 & 48.6 & 50.6 & 44.0 & 39.4 & 30.0 & 25.8 & 55.2 & 29.2 & 48.6 & 48.2 & 42.0 \\
\hline & 400 & 58.4 & 63.0 & 64.6 & 38.0 & 36.0 & 30.8 & 31.4 & 41.4 & 66.8 & 76.8 & 54.7 \\
\hline
\end{tabular}


られた。

一方, 対照とした EHL では先端出力 $200 \mathrm{~mJ}$ (使用装 置の最低出力）で作動させた場合，10回測定の平均が

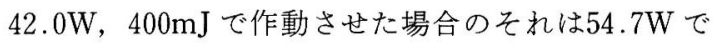
あった。すなわちレーザー砕石装置の発生させる衝撃 波は, EHLのそれに比較し, 前述の条件で測定した場 合約100分の 1 という弱いものであることが判った。

実際の結石に対する砕石効果では，シスチン結石以 外の結石はすべて砕石可能であった．とくに長径 $8 \mathrm{~mm}$ 以下の表面が不整で粗な結石はいずれも50〜1,000発 の接触照射が破砕された。さらにビリルビン結石は砕 石が容易であり，10発以下の照射で小片となった。し かしシスチン結石はどのような大きさ, 形の結石でも 何等影響を受けず，砕石不能であった。をた，シスチ ン以外の結石でも，表面が平滑な古く大きい結石では 碎石効果が認められるまでには 3,000 発以上の照射を 要するものもみられた。

3. 小括

一連の実験により，パルス波レーザー砕石装置の先 端出力は, EHL の先端出力に比べ約 100 分の 1 といら 弱いものであるにもかかわらず，シスチン以外の結石 は砕石が可能であることが判明した。このことが組織 への影響は少ないが砕石は可能という本装置の特徵に も関係しているのかも知れない。また, 研石様式は結
石片を周囲に飛び散らすことが少なく，臨床的に使用 した場合，自然排石不能な結石片が残存する可能性は 低いと考光られた。一方，大きな結石では砕石に時間 がかかり，臨床的には，小結石に対して用いるのに適 した砕石装置と思われた。

尚, 本実験で用いた EHLのプローブ先端出力は, あ くまで電気的な計測值である。

\section{生体に及ぼす影響}

\section{1. 実験方法}

エーテル麻酔下でヌードマウスの首から下を生理食 塩水中に固定し, 皮膚・肝・腎・膀脱粘膜にレーザー を接触照射した。実験終了後屠殺し照射部位を摘出, ホルマリン固定後薄切し H.E 染色を行い病理組織学 的に観察した。レーザー照射条件は $30 \mathrm{~mJ}, 10 \mathrm{~Hz}$ とし た。

また, 前立腺肥大症で経尿道的前立腺切除術 (TURP）施行直前の前立腺部尿道粘膜に内視鏡下でレー ザーを接触照射した，照射部位を切除鏡にて切除し， 病理組織学的に検討した。照射条件はヌードマウスと 同様である.

さらに，カルシウムを含む無機物質を介した場合の 生体への影響を観察するため, 鵎卵を生理食塩水中に 入れ，その表面にレーザーを接触照射した。照射条件 は $30 \mathrm{~mJ}, 10 \mathrm{~Hz}$ である。

図 3 パルス波色素レーザー接触照射によるマウス諸組織の変化 左：肝…被膜の穿孔，実質細胞の構造破壊，核の濃縮を認める.中：腎…被膜の穿孔， 尿細管上皮細胞の変性を認める. 右：皮膚…表皮, 真皮の穿孔, 皮下組織の軽度の浮 腫, 出血を認める.
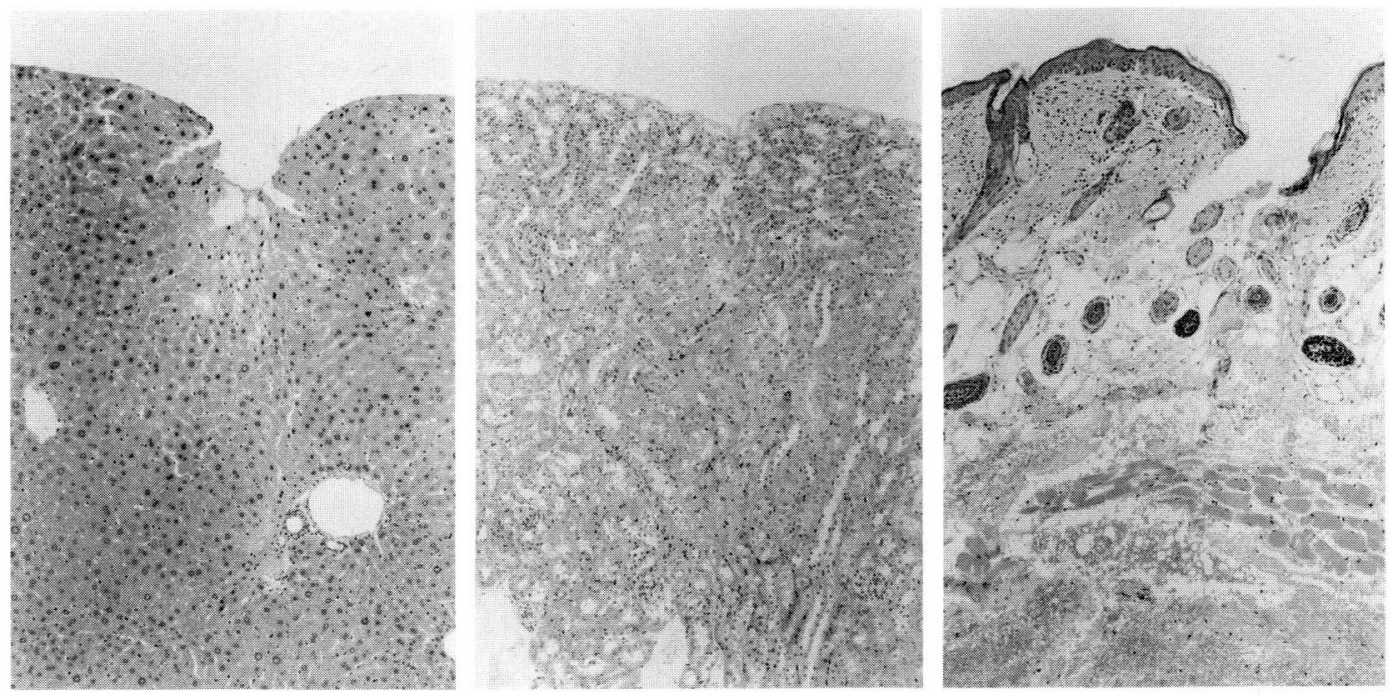


\section{2. 結果}

ヌードマウスの肝・腎の浆膜面への照射では， 5 発 以上で被膜に穿孔をきたし出血を認めた。病理組織学 的には浆膜の穿孔・直下の実質細胞の核の濃縮，細胞 質の均質化がみられ, 間質には軽度の浮腫, 出血を認 めた。 また皮膚への照射では 20 発以上の照射ではじめ て皮膚の穿孔，出血がみられた。しかし膀胱粘膜への 照射では50発照射しても肉眼的には明らかな变化がみ られず，組織学的にも照射部位を同定できなかった。 肝・腎・皮膚の変化はいずれも衝撃力による影響と考 えられ，熱によると思われる変化はみられなかった。 導光ファイバー先端を肝，腎，皮膚などの対象から1 $\mathrm{mm}$ 以上離して照射した場合は，長時間の照射でも肉 眼的, 組織学的に何等変化はみられなかった。

ヒト前立腺部尿道粘膜に対する接触照射では $5 \sim 10$ 発で粘膜に小孔が生じ出血をみた。組織学的検索でも,
同部の粘膜の消失, 粘膜下の軽度の出血が認められた。 鷄卵の卵殼に接触照射した場合, 卵殼は細かい破片 となって脱落したが，その直下の卵膜にはなんの影響 もみられなかった。

3. 小括

実験結果より，ファイバー先端が対象組織に接触し ていないかぎり,レーザー光が当っても組織に何等影 響がないことが確認された。接触照射された場合でも その作用はあくまで衝撃力によるものであり，熱によ る作用はないものと考光られた。我々はかって犬を用 いて EHL が生体に及ぼす直接作用について観察した が3)，その結果と比較するとレーザー砕石装置の影響 は著しく軽微であった。臨床的に用いた際に誤って粘 膜面に接触照射しても尿管，腎盂への影響は軽度であ ろうと想像された。

表 2 対象症例

\begin{tabular}{|c|c|c|c|c|c|c|c|c|}
\hline No. & 氏 名 & 年 齢 & 性 別 & 診 断 名 & 結石の大きさ & 結石の存在部位 & 手術方法 & 効果判症 \\
\hline 1 & S. N. & 69 & $\mathrm{~F}$ & 左腎結石 & $10 \times 9$ & 腎 & PNL & 有効 \\
\hline 2 & D. H. & 79 & M & 右腎結石 & サンゴ状結石 & 腎 & PNL & 無効 \\
\hline 3 & T. H. & 58 & M & 両腎結石 & 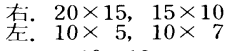 & 腎孟 & PNL & 無効 \\
\hline 4 & K. S. & 64 & M & 左尿管結石 & $13 \times 13$ & 上 部 尿 管 & TUL & 著効 \\
\hline 5 & U.N. & 25 & $\mathrm{~F}$ & 左尿管結石 & $7 \times 6$ & 下 部 尿 管 & TUL & 有効 \\
\hline 6 & M. M. & 67 & M & 右尿管結石 & $9 \times 6$ & 中部尿 管 & PNL & 有効 \\
\hline 7 & K. I . & 46 & M & 右尿管結石 & $11 \times 6$ & 中部尿管 & PNL & 有効 \\
\hline 8 & S. E. & 53 & M & 左尿管結石 & $13 \times 6$ & 下部尿 管 & PNL & 有効 \\
\hline 9 & M. K. & 25 & M & 左腎結石 & $14 \times 8$ & 腎責 & PNL & 無効 \\
\hline 10 & H. I. & 50 & $\mathrm{~F}$ & 右尿管結石 & $7 \times 6$ & 中部 尿 管 & PNL & 有効 \\
\hline 11 & K. N. & 57 & M & 左尿管結石 & $9 \times 9$ & 上部尿 管 & PNL & 無効 \\
\hline 12 & J. H. & 24 & M & 左尿管結石 & $12 \times 10$ & 上 部 尿 管 & PNL & 無効 \\
\hline 13 & H. N. & 43 & M & 左尿管結石 & $18 \times 9$ & 上部 尿 管 & PNL & 有効 \\
\hline 14 & M. Y. & 62 & M & 右尿管結石 & $7 \times 5$ & 上部尿管 & PNL & 有効 \\
\hline 15 & E. N. & 55 & M & 右尿管結石 & $16 \times 7$ & 上部尿 管 & PNL & 著効 \\
\hline 16 & Y. S. & 29 & M & 左尿管結石 & $9 \times 5$ & 上部尿 管 & PNL & 有効 \\
\hline 17 & K. N. & 45 & M & 左尿管結石 & $9 \times 6$ & 上部尿管 & PNL & 有効 \\
\hline 18 & S. K. & 55 & $\mathrm{~F}$ & 左尿管結石 & $15 \times 9$ & 上部 尿 管 & PNL & 著効 \\
\hline 19 & M. N. & 32 & M & 左尿管結石 & $9 \times 4$ & 中部尿管 & PNL & 著効 \\
\hline 20 & T. M. & 57 & M & 左尿管結石 & $17 \times 6.5$ & 下部尿管 & TUL & 著効 \\
\hline 21 & W. K. & 47 & $\mathrm{M}$ & 左尿管結石 & レ線陰性 & 上部尿 管 & PNL & 著効 \\
\hline 22 & K. T. & 26 & M & 左尿管結石 & $13 \times 10$ & 中部尿管 & PNL & 著効 \\
\hline 23 & N. S. & 48 & M & 右尿管結石 & $19 \times 7$ & 下 部 尿 管 & TUL & 無効 \\
\hline 24 & T. Y. & 20 & M & 右尿管結石 & $9 \times 4$ & 中部尿 管 & PNL & 有効 \\
\hline 25 & Y. O. & 57 & $\mathrm{~F}$ & 右尿管結石 & $8 \times 5$ & 下部尿 管 & TUL & 有効 \\
\hline 26 & T. Y. & 19 & M & 左尿管結石 & $12 \times 7$ & 上部尿 管 & PNL & 有効 \\
\hline 27 & T. Y. & 53 & $\mathrm{~F}$ & 左腎結石 & サンゴ状結石 & 腎孟 & PNL & 有効 \\
\hline 28 & H. A. & 27 & M & 右尿管結石 & $13 \times 6$ & 下 部 尿 管 & TUL & 有効 \\
\hline 29 & I. Y. & 40 & $\mathrm{~F}$ & 左尿管結石 & $5 \times 4$ & 上 部 尿 管 & TUL & 著効 \\
\hline 30 & T. I. & 45 & M & 左尿管結石 & $18 \times 9$ & 下部尿 管 & TUL & 有効 \\
\hline
\end{tabular}




\section{臨床的検討}

\section{1. 対象と方法}

対象は昭和 62 年 2 月より 63 年 8 月までに当科に入院 した上部尿路結石症患者で男性23例，女性 7 例の計30 例である。原則として自然排石の期待できない結石， 水腎症が強く，または増悪傾向にある結石， 3 力月以 上尿管の同一部位にある結石を対象とした。症例の平 均年齢は 45.9 歳で，最年少 19 歳，最年長79歳であった。 30 症例中, 腎結石 5 例（サンゴ状結石 2 例, 多発結石 1 例, 単発結石 2 例), 尿管結石 25 例(上部尿管結石 12 例，中部尿管結石 6 例，下部尿管結石 7 例)であった.

手術方法は 5 例の腎結石症例は全例 PNL, 尿管結石 25例中, PNL 17例, TUL 8 例である. 使用した内視 鏡は腎結石の 5 例中 4 例はオリンパス硬性腎孟鏡, 1 例はオリソパス 2 チャンネル軟性腎孟鏡, 尿管結石症 例中17例の PNL 施行例は全て軟性鏡, 8 例の TUL 施行例中 7 例はオリンパス硬性尿管腎孟鏡, 1 例は軟 性鏡を用いた，全例に硬膜外麻酔または腰椎麻酔を施 行した。

レーザー出力は $30 \mathrm{~mJ} \cdot 10 \mathrm{~Hz}$ で砕石を行ったもの 21 例, $40 \mathrm{~mJ} \cdot 10 \mathrm{~Hz} 2$ 例, $50 \mathrm{~mJ} \cdot 10 \mathrm{~Hz} 1$ 例 $50 \mathrm{~mJ} \cdot 5 \mathrm{~Hz} 6$ 例であった。

レーザー砕石装置の効果判断基準として，著効（目 的とする結石を全て充分に研石), 有効(目的とする結 石を大部分砕石)，無効（ほとんど砕石不能）とした。 しかし，レーザー砕石装置は砕石のみであり，やや大 きな砕石片はバスケットカテーテルなどを用いて摘出 する必要があった。したがって砕石できたが他の手段 を用いて結石片を除去したものも有効とした。

安全性については，腎孟・尿管粘膜の穿孔の有無,
内視鏡の視野を括掞らような出血の有無について判定 した。

2. 結果

レーザー砕石装置で満足のゆく砕石ができなかった

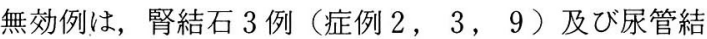
石 3 例（症例 $11 ， 12 ， 23 ）$ 計 6 例であり，他の24例 では著效または有効で，研石有效率としては $80 \%$ と満 足のゆく結果を得た，retrospective に考完ると，砕石 でさなかった 6 例のらち4 例は初期のものでレーザー 照射条件が不充分であったと思われ，2 例は古い大き な結石であり，本来レーザー砕石装置の適応外のもの であったと思われる。

結石成分についてみると，術後成分分析を行った28 例では蓚酸カルシウムと燐酸カルシウムの混合結石が 22例と最も多く，その他，蓚酸カルシウム結石，蓚酸 カルシウムと炭酸カルシウム，燐酵カルシウムと炭酸 カルシウム，燐酸マグネシウムアンモニウムを主体と し各種成分を含む混合結石であった。しかし，結石成 分之砕石効果の間には明らかな関連性はみられなかっ た。

レーザー砕石装置の先端出力についてみると表 3 の ごとくで, 先端出力が大きい方が短時間で砕石された.

表 3 レーザー照射条件と砕石成績

\begin{tabular}{c|r|r|c|c|c}
\hline \multirow{2}{*}{$\begin{array}{c}\text { 出 力 } \\
\text { (mJ/Pulse) }\end{array}$} & \multirow{2}{*}{$\mathrm{Hz}$} & \multicolumn{2}{|c|}{ 砕石成功例 } & \multicolumn{2}{|c}{ 砕石不成功例 } \\
\cline { 3 - 6 } & & 症例数 & 平均照射回数 & 症例数 & 平均照射回数 \\
\hline 30 & 10 & 17 & 1530 & 4 & 2190 \\
40 & 10 & 1 & 245 & 1 & 800 \\
50 & 10 & 0 & & 1 & 803 \\
50 & 5 & 6 & 450 & 0 & \\
\hline
\end{tabular}

図 4 パルス波色素レーザーによる粘膜出血 左：砕石前の結石, 中：ファイバー先端の接触による出血, 右：砕石後（2 時方向の 棒がファイバー先端)

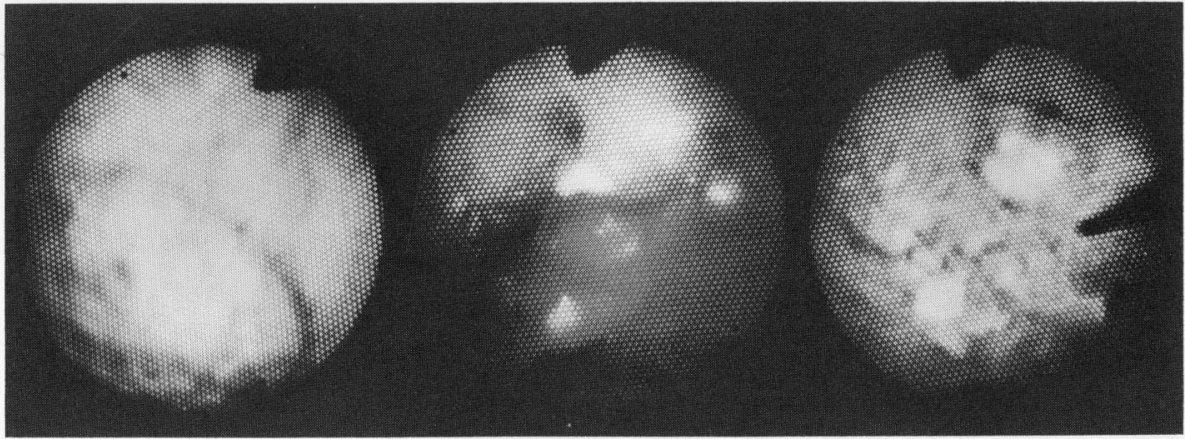


レーザー砕石装置による直接的副作用としては, PNL, TUL 各 1 例(症例 4, 22)で粘膜に直接導光ファ イバー先端が接触したための軽度の出血がみられたの みであったそその他導光ファイバーを内視鏡の working channel に挿入する際に, これを折ってしまうとい ら事故が一度みられた。

我々は, 砕石後は積極的に砕石片の除去につとめ 3 〜 $4 \mathrm{~mm}$ 以上の結石片はバスケットカテーテルで摘出 するよらこころがけた（有効例）が，充分砕石できた と判断し何ら摘出操作を行わなかった 8 例（著効例） では, 砕石片は輔度の stone street を作りながら 1 〜 3 週間で自然排石された。

\section{3. 小括}

30 例の上部尿路結石症例に対しパルス波色素レー ザー砕石装置を用いた砕石をこころみ，80\%に著効な いし有効の結果を得た。 PNL，TULいずれの術式を用 いた群でも，結石の大きさ，存在部位，成分による砕 石効果の差はみられなかった. しかし, 砕石不能であっ た結石は，その多くが表面が平滑なものであった。

\section{考察}

尿路結石の破碎にレーザーを用いようとするこころ

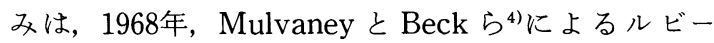
レーザー及び炭酸ガスレーザーを用いた砕石実験が最 初である。本邦でも，東北大学の棚橋ら ${ }^{5) 6}$ が前述の レーザーの他に ND：YAGレーザーも用いた実験を 行っている。これらの実験では結石の一部または全部 が破壊されたものの，その作用は炭酸ガスレーザー， $\mathrm{Nd}$ : YAGレーザーでは熱によるものであり，ルビー レーザーでも熱作用が無視できなかった．最近，これ ら連続波レーザーの熱作用より，パルス波レーザーに よる衝撃波が結石の破壊により効果的であることが判 明し，パルス波の Nd: YAGレーザーを用いた砕石も こころみられている。しかし，パルス波 $\mathrm{Nd}: \mathrm{YAG}$ レーザーも熱による作用があり, 腎孟・尿管粘膜に直 接照射した場合には穿孔をきたす可能性も否定できな い，一方，我々の用いたパルス波色素レーザー砕石装 置は，熱作用はほとんど伴わない衝撃波による砤石装 置である，今回の一連の実験で示されているごとく， レーザーを用いているにもかかわらず，導光ファイ バー先端が対象に接触した状態で照射されてはじめて 効果が出現するといら特徵がある。この特徵は，一面 ではファイバーが届かなければ砕石できないという久 点にもなるが, 安全性の面からは特筆すべき点である。 本装置の砕石原理について, Watson 等 ${ }^{7) 8}$, Dretler
等9は、レーザーエネルギーが結石表面に吸収され，そ の結果, 導光ファイバー先端と結石との間にプラズマ が発生し，その衝撃波により砕石が行われると述べて いる。プラズマ発生に伴ら発熱は, 発生時間が短く実 際のエネルギーも少ないため周囲の水に容易に吸収さ れてしまい，熱による作用は出現しないとしている。 我々の実験においても, 砕石の過程で特有の白色光と 音の発生を認めた。砕石様式はこのレーザーのパルス 幅，パワー密度からその作用が photoablation であろ らと想像されたと扤りであった。すなわち，大きな砕 石片を周囲にまき散らすことなく少しづつ削り取るよ らに砕石した。このため砕石終了後に大きな砕石片の 残存する可能性が少ないという利点が生じた。しかし, 実験結果でも述べたごとく，小結石の破砕にも数百発 といらレーザー発振を要するため, EHLによる砕石に 慣れた者にとっては砕石効果が弱いといら印象を与兄 ることも事実である。

一方, 生体に直接接触照射した場合の影響について, Watson 等は $504 \mathrm{~nm}$ の波長の光はへモグロビンに吸収 されてしまい生体に影響を与えないと述べている。 た，ブタの尿管を用いた砕石実験では，レーザー砕石 装置による副作用はなく，使用する内視鏡の太さに起 因する尿管損傷がより重大であるとしている ${ }^{10)}$. 我々 の実験結果からも, 生体への影響は著しく軽微で, 長 期的な副作用を残す可能性はないといえよう。しかし， 我々は，生体に影響を与えない理由がへモグロビンに よるエネルギーの吸収によるものだけではなく，組織 表面の透明度や色調にも関係するといら印象を受け た。この点は他の結石に比べ透明度の高いシスチン結 石が破砕されないこととも関連するのではないかと思 われたが，さらに検討が必要である。

臨床例30例の経験では，80\%の症例で満足のゆく砕 石効果を得, 副作用としては 2 例で軽度の粘膜出血を みとめたのみであった。充分な砕石効果を得られた症 例の多くは，表面が不整な比較的小さな結石であり， この点から本装置は主に尿管結石に適すると考只られ る.

今回の経験からレーザー砕石装置の長所をあげる と, 第一に細く柔軟な導光ファイバーを使用できる点 である。これにより細径の軟性鏡を用いても充分な潅 流が可能となり，尿管に無理な拡張を強いることもな くなる.第二に生体への影響が著しく少ない点である。 このため安心して砕石操作に専念することができる。 一方, 短所としてはすべてのレーザー装置に共通であ 
るレーザー光から眼を保護する必要がある点に加え， 導光ファイバーが細すぎるといら点があげられる。す なわち，内視鏡下でファイバー先端が見にくく，結石 表面に確実に接触しているか否かの判断が難かしい． しかしこれらは馴れにより，あるいはすぐれたビデオ カメラを接続させることで克服可能である．何といっ ても $0.25 \mathrm{~mm}$ といら細く柔軟なファイバーで生体に大 きな影響を与えることなく選択的に結石を破壊できる 点は大きな魅力である，今後，内視鏡を中心とする周 辺機器の開発に伴いTUL の際の最も有用な砕石装置 としてその位置を占める可能性を持つと思われる。

\section{結 語}

パルス波色素レーザー砕石装置の特性, 生体に及ぼ す影響について実験的に検討した。この結果，生体に は大きな影響を与えない安全な砕石装置であり，シス チン以外の尿路結石は砕石可能であることが判明し た。 また，30症例の上部尿路結石症に臨床的に使用し $80 \%$ の症例で有効な砕石効果を得た. 今後は, TULの 際の最も有用な碎石装置となろう。

本論文の要旨は, 第449回日本泌尿器科学会東京地方会, 第52会日本泌尿器科学会東部連合総会, 第 8 回日本レー ザ一医学会総会, 第76回日本泌尿器科学会総会において報 告した。

\section{文献}

1）秋鹿唯男, 三木 誠, 間宮良美, 松本哲夫, 平田 亨, 清水弘文, 栃本真人, 伊藤貴章 : 新しく開発さ れた超音波碎石装置の使用経験. 泌尿器科紀要, 33, 2010-2015, 1987.
2）間宮良美, 三木 誠, 松本哲夫, 秋鹿唯男, 平田 亨, 清水弘文: 改良型電気水圧碎石器の使用経験。 泌尿器科紀要，33，2032-2037，1987.

3）清水弘文, 松本哲夫, 間宮良美, 秋鹿唯男, 平田 亨, 栃本真人, 伊藤貴章, 三木 誠: USL と EHL の安全性の再検討とその使用手技について。第 51 回日本泌尿器科学会東部総会, 1986, 10, 4.

4) Mulvaney, W.P. and Beck, C.W.: The laser beam in urology. Urol. Res., 4, 49-54, 1976.

5）棚橋善克, 折笠誠一, 千葉隆一, 田平憲一郎, 深津 勉, 宮川 決 : レーザー光線の泌尿器科領域への 応用，第 1 報。日泌尿会誌，70，1-6, 1979 .

6) 棚橋善克, 折笠誠一, 沼田 功, 宮川 決, 田平憲 一郎, 佐藤勝彦, 山本 肇: レーザー光線の泌尿器 科領域への応用, 第 2 報. 日泌尿会誌, 71, 28-32, 1980.

7) Watson, G.M. and Wickham, J.E.A.: Initial experience with a pulsed dye laser for ureteric calculi. Lancet, 14, 1357-1358, 1986.

8) Watson, G., Murray, S., Dretler, S.P. and Parrish, J.A.: The pulsed dye laser for fragmenting urinary calculi. J. Urol., 138, 195-198, 1987.

9) Dretler, S.P., Watson, G., Parrish J.A. and Murray, S.: Pulsed dye laser fragmentation of ureteral calculi : Initial clinical experience. J. Urol., 137, 386-389, 1987.

10) Watson, G., Murray, S., Dretler, S.P. and Parrish, J.A.: An assessment of the pulsed dye laser for fragmenting calculi in the pig ureter. J. Urol., 138, 199-202, 1987.

（1989年 5 月 26 日受理, 特別揭載） 